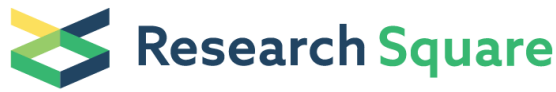 \\ Preprints are preliminary reports that have not undergone peer review. \\ They should not be considered conclusive, used to inform clinical practice, or referenced by the media as validated information.
}

\section{A Comprehensive Molecular Survey of Viral Pathogens Associated with Canine Gastroenteritis During 2018-21}

\author{
Anusha Dema \\ PV Narasimha Rao Telangana Veterinary University: Sri PV Narasimha Rao Telangana State Veterinary University \\ Mounika Tallapally \\ PV Narasimha Rao Telangana Veterinary University: Sri PV Narasimha Rao Telangana State Veterinary University \\ Vishweshwar Kumar Ganji \\ PV Narasimha Rao Telangana Veterinary University: Sri PV Narasimha Rao Telangana State Veterinary University \\ Bhagyalakshmi Buddala \\ PV Narasimha Rao Telangana Veterinary University: Sri PV Narasimha Rao Telangana State Veterinary University \\ Haritha Kodi \\ PV Narasimha Rao Telangana Veterinary University: Sri PV Narasimha Rao Telangana State Veterinary University \\ Ashwini Ramidi \\ PV Narasimha Rao Telangana Veterinary University: Sri PV Narasimha Rao Telangana State Veterinary University \\ Sai Spandana Chenji \\ PV Narasimha Rao Telangana Veterinary University: Sri PV Narasimha Rao Telangana State Veterinary University \\ Jaya Laxmi $P$ \\ PV Narasimha Rao Telangana Veterinary University: Sri PV Narasimha Rao Telangana State Veterinary University \\ Vamsi Krishna S \\ PV Narasimha Rao Telangana Veterinary University: Sri PV Narasimha Rao Telangana State Veterinary University

\section{Narasimha Reddy Yella} \\ PV Narasimha Rao Telangana Veterinary University: Sri PV Narasimha Rao Telangana State Veterinary University \\ Kalyani Putty ( $\sim$ kalyaniputty@gmail.com ) \\ PV Narasimha Rao Telangana Veterinary University: Sri PV Narasimha Rao Telangana State Veterinary University \\ https://orcid.org/0000-0002-9451-3047
}

\section{Research Article}

Keywords: Canine parvovirus-2, Canine distemper virus, Canine adenovirus, Canine coronavirus, Canine astrovirus, Whole genome sequencing.

Posted Date: January 18th, 2022

DOI: https://doi.org/10.21203/rs.3.rs-1249302/v1

License: (c) (i) This work is licensed under a Creative Commons Attribution 4.0 International License. Read Full License 


\section{Abstract}

Viral pathogens account for major aetiology of canine gastroenteritis in India. However, till date, there was no structured comprehensive study reported on the viral aetiology of canine gastroenteritis in India. To elucidate this, 475 rectal swabs collected over a period of three years (2018-2021) from clinical canine gastroenteritis cases were screened by real-time PCR for the presence of six majorly known enteric viruses (Canine parvovirus -2 (CPV-2), canine distemper virus (CDV), canine adenovirus-2 (CAdV-2), canine corona virus (CCoV), canine astrovirus (CaAstV), canine rotavirus (CRV)). $71.6 \%$ of the samples were found to harbour at least one of the five viruses tested (CPV-2/2a/2b/2c, CDV, CAdV-2, CCoV and CaAstV), whereas, there was no evidence of CRV. The overall incidence rate for each virus was found highest at $64.8 \%$ for CPV-2/2a/2b/2c (2a: $21.1 \%, 2 \mathrm{~b}: 77.4 \%, 2 \mathrm{c}: 1.5 \%)$, followed by $8 \%$ for CDV, $7.2 \%$ for CaAstV, $5.9 \%$ for CCoV and $4.6 \%$ for CAdV-2 with $16.8 \%$ incidence for coinfections ranging from two to four viruses in different combinations. Further, for the first time we report the whole genome sequences of CDV, CCoV and CaAstV Indian isolates from canine gastroenteritis cases. Phylogenetic analysis of whole genome revealed that CDV clustered with Asia-1 lineage, CaAstV clustered with group III that consists of China and Brazil isolates, and CCoV clustered with group II that consists of China and Taipei isolates. This study adds to our knowledge on the prevalence of these pathogens in the Indian subcontinent and highlights the need for relevant and routine vaccine prophylactic measures. It is alarming to note that $70.3 \%$ of animals vaccinated with DHPPIL were found positive for at least one virus. Hence, regular molecular analysis of the prevalent viruses is crucial to address vaccination failures.

\section{Highlights}

1. Viral gastroenteritis is a common problem in canines despite routine vaccinations.

2. Exhaustive studies on viral prevalence were sparse, with none reported from India till date.

3. We report molecular survey of enteric viruses from gastroenteritis cases during 2018-21.

4. CPV-2b is the predominant virus, followed by CPV-2a, CPV-2c, CDV, CAdV-2, CCoV, CaAstV.

5. We further report whole genome sequence of CCoV, CaAstV and CDV isolates from dogs in India for the first time.

6. Our study significantly contributes to the knowledge on viral canine gastroenteritis and highlights the need for a dedicated and relevant routine vaccine prophylaxis.

\section{Introduction}

Dog has been the best common companion animal of all the domesticated animals and like humans, they are also prone to several diseases. Gastroenteritis, the irritation of the stomach and intestines is one among them resulting in vomiting and diarrhoea. This can progress quickly and can become very dangerous to the pet's health and, if left untreated, lead to death, especially in young animals. Gastroenteritis can occur for a variety of reasons viz., dietary indiscretion, tumours, metabolic disorders, toxins, and most important of all, infectious agents such as bacteria (Enany et al. 2021), parasites (Headley et al. 2013; Gerardi et al. 2018), and viruses (DiGangi et al. 2019). Viruses were reported to be detected in up to 60\% of diarrhoeic faecal samples (Gizzi et al. 2014).

Canine parvovirus (CPV) (Caddy 2018), Canine distemper virus (CDV) (Quintero-Gil et al. 2019), Canine adenovirus (CAdV) (Ramidi et al. 2020), Canine coronavirus (CCoV) (Buonavoglia et al. 2006), Canine astrovirus (CaAstV) (Fauquet and Fargette 2005), Canine rotavirus (CRV) (Ortega et al. 2017) were frequently reported as a cause for viral gastroenteritis in dogs. CPV belonging to Parvoviridae family is highly contagious and was first identified in dogs suffering from severe hemorrhagic gastroenteritis and myocarditis as CPV-2 variant (Appel et al. 1979; Hoang et al. 2019); later on replaced by three antigenic variants namely CPV-2a, CPV-2b, and CPV-2c (Zhong et al. 2014; Sharma et al. 2016; Chiang et al. 2016; Zhou et al. 2017b). CDV belonging to Paramyxoviridae family is responsible for high mortality rates in dogs worldwide (Quintero-Gil et al. 2019). Haemagglutinin gene of CDV was known to be evolved under genetic drift and was responsible for introduction of genetically different CDV strains (Glardon and Stöckli 1985). It was reported that at least fifteen different lineages of CDV are circulating worldwide (Bhatt et al. 2019; Kodi et al. 2020). CAdV belongs to Adenoviridae family and circulates as two distinct serotypes, CAdV- 1 and CAdV-2 (Mohammadi et al. 2011; Ramidi et al. 2020). Despite routine vaccinations, re-emergence of CAdV-2 was documented throughout the world (Balboni et al. 2014). CCoV belongs Alphacoronavirus 1 of Coronaviridae family, causes mild to moderate enteritis in dogs characterized by high morbidity and low mortality (Buonavoglia et al. 2006). The Alphacoronavirus 1 also include transmissible gastroenteritis virus 
of swine, porcine epidemic diarrhea virus, feline coronaviruses, and human coronavirus 229E (Decaro and Buonavoglia 2008). Canine astrovirus (CaAstV) belonging to Mamastrovirus of Astroviridae family (Fauquet and Fargette 2005) has been detected in multiple countries from diarrheic dogs (Toffan et al. 2009; Martella et al. 2012; Choi et al. 2014; Zhou et al. 2017a). It is mostly known to be associated with mixed viral enteric infections, especially in young dogs (Martella et al. 2011; Zhou et al. 2017a). CRV belongs to Reoviridae family and causes neonatal diarrhea (Ortega et al. 2017).

The aim of the present study is to investigate and delineate the prevalence of major enteric viruses in stool samples from symptomatic dogs. Furthermore, first genome sequences of CDV, CCoV and CaAstV from Indian isolates were also reported along with their phylogenetic analysis.

\section{Materials And Methods}

\section{Clinical sample collection and processing}

Rectal swabs were collected from clinically ill dogs presented with gastroenteritis at Teaching veterinary clinical complex, College of Veterinary Science, Hyderabad and various private clinics in this region. The case histories of 475 samples screened in this study were presented in Table S1. Rectal swabs were collected over a period of three years (2018-2021). The swabs were homogenized in $3 \mathrm{ml}$ of $0.1 \mathrm{M}$ PBS (pH 7.4) containing antibiotics (100 IU/ml Benzyl Penicillin, $100 \mu \mathrm{g} / \mathrm{ml}$ Streptomycin sulphate), centrifuged at $6000 \mathrm{rpm}$ for $10 \mathrm{~min}$ at $4^{\circ} \mathrm{C}$ and the supernatant filtered through $0.22 \mu$ syringe filter was used for further analysis.

\section{Viral Nucleic Acid Extraction And Reverse Transcription}

Viral nucleic acid extraction and reverse transcription

The viral RNA was extracted using TRIZOL ${ }^{\circledR}$ reagent (Ref:15596018; Ambion ${ }^{\circledR}$ ) and the cDNA was synthesized using PrimeScript first strand cDNA Synthesis kit (Cat No.6110A; TaKaRa) following the manufacturer's protocol. The viral DNA was extracted using phenol chloroform and isoamyl alcohol method as described by Sambrook and Russel (Sambrook and Russell 2001).

\section{Screening of clinical samples for viral etiology by real time PCR}

The cDNA or viral DNA served as a template for PCR. The real time PCR was carried out with SYBR® Premix Ex TaqTM PCR Master Mix (Cat.No.RR420A; TaKaRa) in Step One Plus real-time PCR system (Applied Biosystems). The primers used for initial screening of six viruses in individual reactions were listed in the Table 1; along with the real-time PCR reaction conditions. The antigenic typing of CAdV was done into CAdV-1 and CAdV-2 based on the difference in melting temperature (Balboni et al. 2015). The antigenic typing for CPV-2/2a/2b/2c was done by a modified version of TARMS-PCR reported before (Dema et al. 2021). 
Table 1

Primers used for initial screening of viruses

\begin{tabular}{|c|c|c|c|c|c|c|c|}
\hline $\begin{array}{l}\text { S. } \\
\text { No. }\end{array}$ & $\begin{array}{l}\text { Primer } \\
\text { name }\end{array}$ & Primer sequence & $\begin{array}{l}\text { Target } \\
\text { gene }\end{array}$ & Virus & $\begin{array}{l}\text { Amplicon } \\
\text { size }\end{array}$ & $\begin{array}{l}\text { PCR } \\
\text { conditions }\end{array}$ & Reference \\
\hline \multirow[t]{2}{*}{1.} & CPV-F & 5'AAACAGGAATTAACTATACTAATATATTTA3' & \multirow[t]{2}{*}{ VP-2 } & \multirow[t]{2}{*}{ CPV } & \multirow[t]{2}{*}{90} & \multirow{12}{*}{$\begin{array}{l}\text { Initial } \\
\text { denaturation } \\
\text { at } 95^{\circ} \mathrm{C} \text { for } 5 \\
\text { min } \\
\text { followed by } \\
4 \text { cycles of } \\
95^{\circ} \mathrm{C} \text { for } 30 \\
\text { sec and } \\
60^{\circ} \mathrm{C} \text { for } 1 \\
\text { min. Melt } \\
\text { curve was } \\
\text { set starting } \\
\text { at } 50^{\circ} \mathrm{C} \text { to } \\
95^{\circ} \mathrm{C} \text { with a } \\
\text { ramp speed } \\
\text { of } 1 \% \text {. }\end{array}$} & \multirow{2}{*}{$\begin{array}{l}\text { (Decaro } \\
\text { et al. } \\
2005 \text { ) }\end{array}$} \\
\hline & CPV-R & 5'AAATTTGACCATTTGGAT AAACT3' & & & & & \\
\hline \multirow[t]{2}{*}{2.} & CAdV-F & 5'AGTAATGGAAACCTAGGGG3' & \multirow[t]{2}{*}{ E3 } & \multirow[t]{2}{*}{ CAdV } & \multirow[t]{2}{*}{166} & & \multirow{2}{*}{$\begin{array}{l}\text { (Balboni } \\
\text { et al. } \\
2015 \text { ) }\end{array}$} \\
\hline & CAdV-R & 5’TCTGTGTTTCTGTCTTGC3' & & & & & \\
\hline \multirow[t]{2}{*}{3.} & CDV-F & 5'AGCTAGTTTCATCTTAACTATCAAАTT3' & \multirow[t]{2}{*}{$\mathrm{N}$} & \multirow[t]{2}{*}{ CDV } & \multirow[t]{2}{*}{87} & & \multirow{2}{*}{$\begin{array}{l}\text { (Elia et al. } \\
2006 \text { ) }\end{array}$} \\
\hline & CDV-R & 5’TTAACTCTCCAGAAAACTCATGC3' & & & & & \\
\hline \multirow[t]{2}{*}{4.} & CaAstV- & 5’GTACTATACCRTCTGATTTAATT3' & \multirow[t]{2}{*}{ ORF1b } & \multirow[t]{2}{*}{ CaAstV } & \multirow[t]{2}{*}{293} & & \multirow{2}{*}{$\begin{array}{l}\text { (Martella } \\
\text { et al. } \\
\text { 2011) }\end{array}$} \\
\hline & $\begin{array}{l}\text { CaAstV- } \\
\mathrm{R}\end{array}$ & 5'AGACCAARGTGTCATAGTTCAG3' & & & & & \\
\hline \multirow[t]{2}{*}{5.} & CCoV-F & 5'TTGATCGTTTTTATAACGGTTCTACAA3' & \multirow[t]{2}{*}{ M } & \multirow[t]{2}{*}{$\mathrm{CCoV}$} & \multirow[t]{2}{*}{99} & & \multirow{2}{*}{$\begin{array}{l}\text { (Decaro } \\
\text { et al. } \\
2004 \text { ) }\end{array}$} \\
\hline & CCoV-R & 5'AATGGGCCATAATAGCCACATAAT3' & & & & & \\
\hline \multirow[t]{2}{*}{6.} & CRV-F & 5’TTAGATACTACAAGTAATGGAATCGGATGT3' & \multirow[t]{2}{*}{ VP7 } & \multirow[t]{2}{*}{ CRV } & \multirow[t]{2}{*}{76} & & \multirow{2}{*}{$\begin{array}{l}\text { (Logan et } \\
\text { al. 2006) }\end{array}$} \\
\hline & CRV-R & 5'TGGGTGTCATTTGATACAACTTCA3' & & & & & \\
\hline
\end{tabular}

\section{Isolation Of Virus In Cell Lines}

DMEM containing 1\% FBS was used for maintenance of Madin-Darby Canine Kidney (MDCK), A-72 (Canine fibroblast) or EpsteinBarr virus-transformed marmoset $B$ lymphoblastoid (B95a) cell lines at $37^{\circ} \mathrm{C}$ under $5 \% \mathrm{CO}_{2}$. The cells were kept in maintenance media during virus propagation. For virus isolation, the faecal samples were emulsified in PBS and the clear supernatant was used as a seed for virus culture. The virus isolation for CAdV-2, CPV-2/2a/2b/2c and CaAstV were carried out in MDCK cells, whereas for $\mathrm{CDV}$ and $\mathrm{CCOV}, \mathrm{B} 95 \mathrm{a}$, and $\mathrm{A}-72$ cells, respectively were used. The cells were incubated at $37^{\circ} \mathrm{C}$ under $5 \% \mathrm{CO}_{2}$ and were observed for CPE such as granulation, rounding or detachment of cells in clusters disturbing the confluent monolayer. The cells were freezethawed three times and the viral supernatant was used as a seed for subsequent passages.

\section{Whole Genome Sequence Analysis}

The viral RNA was sent to the sequencing facility MedGenome Labs Ltd., Karnataka, India for whole genome sequencing. Briefly, the whole genome was sequenced using HiseqX (Illuminia). Around $12.3 \mathrm{~Gb}$ data was generated with 81 million reads for CaAstV and $14 \mathrm{~Gb}$ data was generated with 95 million reads for CDV and CCoV. The average Q30\% of above $80 \%$ is considered. The reads were first aligned to canine genome (GCF_000002285.3_CanFam3.1) and the unaligned reads were then aligned to respective reference viral genome. De novo assembly was performed using metaspades to obtain scaffolds. The scaffolds were subjected to gene prediction using Prodigal and the predicted ORFs are subjected to Blastx. The sequences were deposited in the NCBI database using online Banklt submission form.

\section{Phylogenetic Analysis}

Predicted viral genome was subjected to BLASTn. At least 15 sequences from the Blastn results were randomly collected based on percentage identity. Multiple sequence alignment was performed using MUSCLE algorithm in MEGAX software and was exported to MEGA file format. The phylogenetic tree was reconstructed using Neighbour Joining algorithm in MEGAX software by setting the test of phylogeny as bootstrap method and number of replicates as 1000 (Kumar et al. 2018). The clades were divided according to 
geographical distribution or as per relativeness in to different lineages/groups. Further, the phylogenetic tree was reconstructed based on the individual gene sequences of CDV, CaAstV and CCoV as similar to above. Sequences of ten isolates per gene distributed geographically were collected from Genbank and all the genes of the virus were run in single analysis for better pictorial representation.

\section{Results And Discussion}

Most of the clinical presentations in dogs involve gastroenteritis, more often with viral aetiology. In the present study, we screened the rectal swabs from 475 clinically suspected dogs for the presence of either of six viruses namely, CPV-2/2a/2b/2c, CDV, CAdV-2, $\mathrm{CCoV}, \mathrm{CRV}$ and CaAstV that are the most common aetiology of viral gastroenteritis.

\section{Prevalence Rate Of Gastroenteritis Causing Viruses}

Being a highly sensitive, rapid, and specific technique that can detect low titre viruses, real-time PCR was successfully being used for molecular screening of clinical samples for viruses (Decaro et al. 2005). Initial screening for viral aetiology showed that around $71.6 \%$ of gastroenteritis cases were infected with either one or a mixture of the five tested viruses, whereas none of them tested positive for the presence of CRV (Table S1). Based on a previous molecular survey in symptomatic dogs, viral aetiology in gastroenteritis cases can go up to $93 \%$ (Zobba et al. 2021). Fig. 1a and Table S2 show the detailed prevalence rate for the viruses that tested positive upon initial screening by real-time PCR. The overall incidence rate for each virus was found highest at $64.8 \%$ for CPV-2/2a/2b/2c, followed by $8 \%$ for CDV, $7.2 \%$ for CaAstV, $5.9 \%$ for CCoV and $4.6 \%$ for CAdV-2. Further, the antigenic typing of highly prevalent CPV-2/2a/2b/2c by TARMS-PCR revealed CPV-2b as the most prevalent antigenic type followed by CPV-2a, and CPV-2c (Fig. 1b and Table S3). It was previously reported that the prevalence rate for CPV-2/2a/2b/2c would be in the range of $50-$ 70\% (Kumar and Nandi 2010; Abedi et al. 2018), for CDV to be around 2\% (Ashmi et al. 2017; Agnihotri et al. 2018), for CaAstV in the range of 9-40\% (Takano et al. 2015; Zhou et al. 2017a; Li et al. 2018), for CCoV in the range of 8-65\% (Ntafis et al. 2013; Wang et al. 2016; Agnihotri et al. 2018), and around 60\% for CAdV (Balboni et al. 2014; DiGangi et al. 2019). The prevalence rate of viruses may depend on age of the dog ( $1 \mathrm{~m}$ - 5years), geographical distribution and environmental factors. We observed that apart from $\mathrm{CPV}-2 / 2 \mathrm{a} / 2 \mathrm{~b} / 2 \mathrm{c}$ all other infections occurred mostly in combination with other viruses, especially with CPV- 2 . The incidence rate for coinfections ranging from two to four viruses in different combinations accounted for $16.8 \%$. It was previously reported that the mixed infections with different viral combinations was much common in dogs with gastroenteritis (Pratelli et al. 2001; Damián et al. 2005; Chvala et al. 2007; Headley et al. 2013; Zobba et al. 2021). In conjunction with previous reports (Pratelli et al. 2001; Headley et al. 2013; Zobba et al. 2021), we suggest that the gastroenteritis cases may be screened for mixed infections for effective treatment. Most of the pet owners failed to provide proper history as there was no pet health record maintained with them. Of the animals for which the vaccination history was available, it was interesting to note $70.3 \%$ of the animals vaccinated with DHPPIL were found positive for at least one of the viruses in question. This observation alerts the need to focus on updating the vaccine with circulating strains of the viruses. Moreover, it highlights the need for regular molecular and serological screening of prevalent viruses to address the vaccination failures.

\section{Recovery Of Virus Isolates In Cell Lines}

Because of the presence of mixed infections, especially with CPV-2 a highly virulent virus (Nandi and Kumar 2010), it was difficult to obtain virus isolates from MDCK cells alone. Hence for isolation of CDV and CCoV we used specialized cell lines such as B95a (Pawar et al. 2011) and A-72 (Pratelli et al. 2003). The virus isolates were recovered by infecting the respective cell lines as described in previous section. We observed CPE after 5 dpi for CDV in B95a cells, 3 dpi for CPV-2/2a/2b/2c, CaAstV and 5 dpi for CAdV-2 in MDCK cells, 5 dpi for CCoV in A-72 cells (Fig. 2).

\section{Whole Genome Sequencing Based Evolutionary Dynamics}

Worldwide, there were limited reports of whole-genome sequences of CDV, CCoV and CaAstV isolated from dogs (Caddy and Goodfellow 2015; Romanutti et al. 2020; He et al. 2020); and we found no reports from India, till date. Hence, the whole genome of 
the three viruses (CDV, CaAstV, CCoV) was sequenced, extracted and the ORF regions were predicted. The total genomic length was found to be around $15.6 \mathrm{~kb}$ for CDV, $6.5 \mathrm{~kb}$ for CaAstV, $29 \mathrm{~kb}$ for CCoV which was nearly similar to that of the previous reports (Von Messling et al. 2001; Carstens 2010; Mihalov-Kovács et al. 2017). We found six ORFs (N, M, F, H, L, P) for CDV; three ORFs for CaAstV (ORF-1a, 1b, 2); and two overlapping ORFs coding ORF-1a and RdRp genes along with nine other genes (M, S, E, N, ORF-3a, 3b, 3c and ORF-7a, 7b) for CCoV as similar to earlier reports (Von Messling et al. 2001; Martella et al. 2011; Garcia 2016). The complete sequences along with protein-coding regions were deposited in the GenBank database of NCBI using Banklt submission and the accession numbers are MT905031 for CDV, MT894143 for CaAstV and MT955604 for CCoV. The whole-genome sequence of CDV was clustered with Asia-1 lineage that was distant from vaccine lineage (Fig. 3a), CaAstV was clustered with group III that consists of China and Brazil isolates when divided into three groups based on the relatedness (Fig. 3b). CCoV was clustered with group II that consists of China and Taipei isolates when divided into two groups based on the relatedness (Fig. 3c). A previous study suggested that all wild type strains of CDV clustered in a similar way to the groups obtained as in $\mathrm{H}$ gene analysis, which is normally used to identify geographically distinct CDV lineages (Romanutti et al. 2020). We observed a similar grouping in this study. Further, we also noticed that all the wild type strains are genetically distant to vaccine strains (Martella et al. 2006; Zhao et al. 2010). For CaAstV and CCoV, we could only find very limited reports of whole genome based phylogenetic analysis based on geographical distribution. A study reported a similar observation for CaAstV where one of the strains they sequenced got clustered with China isolates (Caddy and Goodfellow 2015). Another study reported that the CCoV isolates from five provinces of China during 2018-19 clustered with the earlier isolates from China similar to our observations (He et al. 2020).

Further, to understand the phylogeny with respect to individual orfs of each of the viruses, the phylogenetic tree based on individual genes of the respective viruses using ten different geographically distinct sequences for each was reconstructed. To our knowledge, very few of such reports on these viruses were published before ( $\mathrm{Li}$ et al. 2018). Most of the reports relied on partial or complete sequence of one or two variable genes in total (Swati et al. 2015; Navarro et al. 2017; Zhou et al. 2017a; Li et al. 2018). Hence, it is noteworthy to understand if there exists any difference in evolutionary relationship with respect to individual genes. The isolates were grouped based on the relatedness; the geographical lineages can't be tested as the number of isolates collected were only ten. Fig. 4 a shows that the current CDV isolate was clustered under M-2 of 3 groups for $M$ gene, L-3 of 3 groups for $L$ gene, $\mathrm{H}-1$ of 2 groups for $\mathrm{H}$ gene, $\mathrm{N}-2$ of 3 groups for $\mathrm{N}$ gene, $\mathrm{F}-2$ of 3 groups for $\mathrm{Fgene}, \mathrm{P} / \mathrm{C}-1$ of 2 groups for $\mathrm{P} / \mathrm{C}$ gene. Though the isolates interchanged in between groups with respect to genes, the current isolate always clustered with China and Europe isolates except for $L$ and $F$ genes, which got clustered with North America and African isolates. However, the whole genome analysis shows clustering with Asia-1 lineage. Fig. $4 \mathrm{~b}$ shows that the current CaAstV isolate was clustered under ORF-1a-1 of 3 groups for ORF-1a, ORF-2-3 of 3 groups for ORF-2. However, the ORF-1b of all showed high level of similarity so that all the isolates were clustered together. The variation in molecular evolutionary relationship is varying greatly for individual gene for CaAstV as the current isolate is clustered with China isolates with respect to $O R F-1 a$ analysis, South America and Europe isolates with respect to ORF-2 analysis, and all the isolates show similarity with respect to ORF-1 $b$ analysis. The ORF-2 phylogeny was similar to that of the whole genome for CaAstV. Fig. 4c shows that the current CCoV isolate was clustered under ORF-1a-2 of 4 groups for ORF-1a gene, ORF-3a-3 of 4 groups for ORF-3a gene, ORF-3b-4 of 4 groups for ORF-3b gene, rdrp-2 of 4 groups for rdrp gene, N-1 of 3 groups for $N$ gene, E-1 of 2 groups for $E$ gene, S-3 of 3 groups for $S$ gene, M-3 of 4 groups for $M$ gene, ORF-7b-2 of 2 groups for ORF-7b gene, ORF-7a-1 of 3 groups for ORF-7a gene, ORF-3c-2 of 4 groups for ORF-3c gene. Similar to CDV, there was shuffling of lineages with respect to individual orfs. The current isolate always clustered with China and Europe isolates except for $E$ and $O R F-3 c$ genes, which got clustered with North America, China and Europe isolates; and Europe isolates, respectively. However, the whole genome analysis show clustering with group II, which has Chinese isolates. Our observations were consistent with the previous reports on independent evolution of genes and various selection pressures and/or evolutionary constraints for various genomic regions (Lukashov and Goudsmit 2002; Li et al. 2018). From this study we understood that the molecular evolutionary dynamics were changing with respect to the individual genes in some cases.

\section{Conclusions}

From the present study we conclude that all the three antigenic variants of CPV-2 (CPV-2a/2b/2c), CDV, CaAstV, CAdV-2 and CCoV were circulating in India during the period of 2018-21. CPV-2b was found to be the most prevalent antigenic variant of all the gastroenteritis viruses surveyed in this study. We notice that majority of the gastroenteritis cases presented to the clinics were infected with at least one virus and the number of viruses infecting each dog range from one to four. To our knowledge, this is the 
first study to report the whole genome sequences of the CDV, CAstV and CCoV viruses isolated in dogs from India. The phylogenetic analysis shows the isolates were distant to that of the vaccine strains. We strongly emphasize on the need for developing a relevant vaccine with circulating variants of viruses for canine gastroenteritis.

\section{Declarations}

\section{Acknowledgments}

The authors acknowledge PV Narsimha Rao Telangana Veterinary University, Hyderabad for providing a research platform and DBT, India for the financial support.

\section{Funding sources}

This work was supported by the DBT, India (No.BT/ADV/Canine Health/TANUVAS).

\section{Competing Interests}

The authors have no relevant financial or non-financial interests to disclose.

\section{Author Contributions}

All authors contributed to the study conception and design. Material preparation, data collection were performed by Anusha Dema, Mounika Tallapally, Bhagyalakshmi Buddala, Haritha Kodi, Ashwini Ramidi and Sai Spandana Chenji. Analysis was done by Vishweshwar Kumar Ganji,Jaya Laxmi P, Vamsi Krishna S, Narasimha Reddy Yella, Kalyani Putty. The first draft of the manuscript was written by Vishweshwar Kumar Ganji and Kalyani Putty. All authors commented on previous versions of the manuscript. All authors read and approved the final manuscript.

\section{Data Availability}

All data generated and analysed during this study are included in this published article and its supplementary information files. The whole genome sequence datasets generated during the current study are available in the NCBI GenBank database repository as accession no. MT905031 for CDV, MT894143 for CaAstV and MT955604 for CCoV.

\section{Ethics Approval}

The current study does not involve human/animal experimentation;hence, ethical approval is not needed. Although dogs were usedin this study for collection of rectal swabs, they were not subjectedto any form of treatment or experimentation. Rectal swabs were collected by a licensed veterinarian.

\section{Consent to participate}

Informed consent was obtained from animal owners for collection of samples

\section{Consent to publish}

Not applicable for the current study.

\section{References}

1. Abedi N, Staji H, Shahroozian E (2018) Frequency of Canine Parvovirus Type-2 Variants by PCR in Enteric and Healthy Dogs and Genotyping of Variants by Restriction Enzyme (RE) Mapping by Ddel Endonuclease Based on Partial VP-2 Gene Sequence. Mol Genet Microbiol Virol 33:151-155. https://doi.org/10.3103/S0891416818020027

2. Agnihotri D, Maan S, Batra K, Jain VK (2018) Comparative Evaluation of Immunochromatographic and Reverse Transcriptase Polymerase Chain Reaction based tests for Diagnosis of Canine Distemper. Intas Polivet 19:414-419 
3. Appel MJ, Scott FW, Carmichael LE (1979) Isolation and immunisation studies of a canine parco-like virus from dogs with haemorrhagic enteritis. Vet Rec 105:156-159. https://doi.org/10.1136/vr.105.8.156

4. Ashmi JM, Thangavelu A, Senthilkumar TMA, Manimaran K (2017) Molecular characterization of canine distemper virus from Tamil Nadu, India. Indian J Anim Sci 87:1062-1067

5. Balboni A, Dondi F, Prosperi S, Battilani M (2015) Development of a SYBR Green real-time PCR assay with melting curve analysis for simultaneous detection and differentiation of canine adenovirus type 1 and type 2. J Virol Methods 222:34-40. https://doi.org/10.1016/j.jviromet.2015.05.009

6. Balboni A, Mollace C, Giunti M, et al (2014) Investigation of the presence of canine adenovirus (CAdV) in owned dogs in Northern Italy. Res Vet Sci 97:631-636. https://doi.org/10.1016/j.rvsc.2014.10.010

7. Bhatt M, Rajak KK, Chakravarti S, et al (2019) Phylogenetic analysis of haemagglutinin gene deciphering a new genetically distinct lineage of canine distemper virus circulating among domestic dogs in India. Transbound Emerg Dis 66:1252-1267. https://doi.org/10.1111/tbed.13142

8. Buonavoglia C, Decaro N, Martella V, et al (2006) Canine coronavirus highly pathogenic for dogs. Emerg Infect Dis 12:492-494. https://doi.org/10.3201/eid1203.050839

9. Caddy SL (2018) New viruses associated with canine gastroenteritis. Vet J 232:57-64. https://doi.org/10.1016/j.tvjl.2017.12.009

10. Caddy SL, Goodfellow I (2015) Complete genome sequence of canine astrovirus with molecular and epidemiological characterisation of UK strains. Vet Microbiol 177:206-213. https://doi.org/10.1016/j.vetmic.2015.03.011

11. Carstens EB (2010) Ratification vote on taxonomic proposals to the International Committee on Taxonomy of Viruses (2009). Arch Virol 155:133-146. https://doi.org/10.1007/s00705-009-0547-x

12. Chiang SY, Wu HY, Chiou MT, et al (2016) Identification of a novel canine parvovirus type 2c in Taiwan. Virol J 13:160. https://doi.org/10.1186/s12985-016-0620-5

13. Choi S, Lim SI, Kim YK, et al (2014) Phylogenetic analysis of astrovirus and kobuvirus in Korean dogs. J Vet Med Sci 76:11411145. https://doi.org/10.1292/jvms.13-0585

14. Chvala S, Benetka V, Möstl K, et al (2007) Simultaneous canine distemper virus, canine adenovirus type 2, and Mycoplasma cynos infection in a dog with pneumonia. Vet Pathol 44:508-512. https://doi.org/10.1354/vp.44-4-508

15. Damián M, Morales E, Salas G, Trigo FJ (2005) Immunohistochemical detection of antigens of distemper, adenovirus and parainfluenza viruses in domestic dogs with pneumonia. J Comp Pathol 133:289-293.

https://doi.org/10.1016/j.jcpa.2005.05.005

16. Decaro N, Buonavoglia C (2008) An update on canine coronaviruses: Viral evolution and pathobiology. Vet. Microbiol. $132: 221-234$

17. Decaro N, Elia G, Martella V, et al (2005) A real-time PCR assay for rapid detection and quantitation of canine parvovirus type 2 in the feces of dogs. Vet Microbiol 105:19-28. https://doi.org/10.1016/j.vetmic.2004.09.018

18. Decaro N, Pratelli A, Campolo M, et al (2004) Quantitation of canine coronavirus RNA in the faeces of dogs by TaqMan RT-PCR. J Virol Methods 119:145-150. https://doi.org/10.1016/j.jviromet.2004.03.012

19. Dema A, Ganji VK, Yella NR, Putty K (2021) A novel one-step amplification refractory mutation system PCR (ARMS-PCR) for differentiation of canine parvovirus-2 variants. Virus Genes 2021575 57:426-433. https://doi.org/10.1007/S11262-02101861-W

20. DiGangi BA, Dingman PA, Grijalva CJ, et al (2019) Prevalence and risk factors for the presence of serum antibodies against canine distemper, canine parvovirus, and canine adenovirus in communities in mainland Ecuador. Vet Immunol Immunopathol 218:. https://doi.org/10.1016/j.vetimm.2019.109933

21. Elia G, Decaro N, Martella V, et al (2006) Detection of canine distemper virus in dogs by real-time RT-PCR. J Virol Methods 136:171-176

22. Enany M, Wahdan A, El-Metwaly M, et al (2021) Bacterial Causes of Hemorrhagic Gastroenteritis in Dogs and Cats with Detection of Some Virulence and $\beta$-lactamase Resistance Genes in Escherichia coli and Salmonella by Multiplex PCR. Suez Canal Vet Med Journal SCVMJ 0:0-0. https://doi.org/10.21608/scvmj.2021.62502.1030 
23. Fauquet CM, Fargette D (2005) International Committee on Taxonomy of Viruses and the 3,142 unassigned species. Virol. J. 2:64

24. Garcia RDCNC (2016) Molecular Characterization of Canine Coronavirus. In: Animal Coronaviruses. Nature Publishing Group, pp 189-198

25. Gerardi F, Santaniello A, Del Prete L, et al (2018) Parasitic infections in dogs involved in animal-assisted interventions. Ital J Anim Sci 17:269-272. https://doi.org/10.1080/1828051X.2017.1344937

26. Gizzi ABDR, Oliveira ST, Leutenegger CM, et al (2014) Presence of infectious agents and co-infections in diarrheic dogs determined with a real-time polymerase chain reaction-based panel. BMC Vet Res 10:23. https://doi.org/10.1186/1746-6148$10-23$

27. Glardon O, Stöckli R (1985) Staupeepidemie in der Schweiz: Epidemiologie und Impfanamnese. Schweiz Arch Tierheilkd 127:707-716

28. He HJ, Zhang W, Liang J, et al (2020) Etiology and genetic evolution of canine coronavirus circulating in five provinces of China, during 2018-2019. Microb Pathog 145:104209. https://doi.org/10.1016/j.micpath.2020.104209

29. Headley SA, Alfieri AA, Fritzen JTT, et al (2013) Concomitant canine distemper, infectious canine hepatitis, canine parvoviral enteritis, canine infectious tracheobronchitis, and toxoplasmosis in a puppy. J Vet Diagnostic Investig 25:129-135. https://doi.org/10.1177/1040638712471344

30. Hoang M, Lin WH, Le VP, et al (2019) Molecular epidemiology of canine parvovirus type 2 in Vietnam from November 2016 to February 2018. Virol J 16:52. https://doi.org/10.1186/s12985-019-1159-z

31. Kodi H, Ganji VK, Bhagyalakshmi B, et al (2020) H Gene-based Molecular Characterization of Field Isolates of Canine Distemper Virus from Cases of Canine Gastroenteritis. Indian J Anim Res Issue: https://doi.org/10.18805/ijar.b-3989

32. Kumar M, Nandi S (2010) Molecular Typing of Canine Parvovirus Variants by Polymerase Chain Reaction and Restriction Enzyme Analysis. Transbound Emerg Dis 57:458-463. https://doi.org/10.1111/j.1865-1682.2010.01167.x

33. Kumar S, Stecher G, Li M, et al (2018) MEGA X: Molecular evolutionary genetics analysis across computing platforms. Mol Biol Evol 35:1547-1549. https://doi.org/10.1093/molbev/msy096

34. Li M, Yan N, Ji C, et al (2018) Prevalence and genome characteristics of canine astrovirus in southwest China. J Gen Virol 99:880-889. https://doi.org/10.1099/jgv.0.001077

35. Logan C, O'Leary JJ, O'Sullivan N (2006) Real-time reverse transcription-PCR for detection of rotavirus and adenovirus as causative agents of acute viral gastroenteritis in children. J Clin Microbiol 44:3189-3195. https://doi.org/10.1128/JCM.0091506

36. Lukashov V V., Goudsmit J (2002) Evolutionary relationships among Astroviridae. J Gen Virol 83:1397-1405. https://doi.org/10.1099/0022-1317-83-6-1397

37. Martella V, Cirone F, Elia G, et al (2006) Heterogeneity within the hemagglutinin genes of canine distemper virus (CDV) strains detected in Italy. Vet Microbiol 116:301-309. https://doi.org/10.1016/j.vetmic.2006.04.019

38. Martella V, Moschidou P, Catella C, et al (2012) Enteric disease in dogs naturally infected by a novel canine astrovirus. J Clin Microbiol 50:1066-1069. https://doi.org/10.1128/JCM.05018-11

39. Martella V, Moschidou P, Lorusso E, et al (2011) Detection and characterization of canine astroviruses. J Gen Virol 92:18801887. https://doi.org/10.1099/vir.0.029025-0

40. Mihalov-Kovács E, Martella V, Lanave G, et al (2017) Genome analysis of canine astroviruses reveals genetic heterogeneity and suggests possible inter-species transmission. Virus Res 232:162-170. https://doi.org/10.1016/j.virusres.2016.12.005

41. Mohammadi A, Masoudian M, Nemati Y (2011) Evaluation of PCR techniques for detection and differentiation of canine adenoviruses in faecal samples in Shiraz, Iran. Bulg J Vet Med 14:251

42. Nandi S, Kumar M (2010) Canine parvovirus: Current perspective. Indian J. Virol. 21:31-44

43. Navarro R, Nair R, Peda A, et al (2017) Molecular characterization of canine parvovirus and canine enteric coronavirus in diarrheic dogs on the island of St. Kitts: First report from the Caribbean region. Virus Res 240:154-160.

https://doi.org/10.1016/j.virusres.2017.08.008

Page 9/13 
44. Ntafis V, Mari V, Decaro N, et al (2013) Canine coronavirus, Greece. Molecular analysis and genetic diversity characterization. Infect Genet Evol 16:129-136. https://doi.org/10.1016/j.meegid.2013.01.014

45. Ortega AF, Martínez-Castañeda JS, Bautista-Gómez LG, et al (2017) Identification of co-infection by rotavirus and parvovirus in dogs with gastroenteritis in Mexico. Brazilian J Microbiol 48:769. https://doi.org/10.1016/J.BJM.2017.03.008

46. Pawar RM, Raj GD, Gopinath VP, et al (2011) Isolation and molecular characterization of canine distemper virus from India. Trop Anim Health Prod 43:1617-1622. https://doi.org/10.1007/s11250-011-9880-7

47. Pratelli A, Martella V, Decaro N, et al (2003) Genetic diversity of a canine coronavirus detected in pups with diarrhoea in Italy. J Virol Methods 110:9-17. https://doi.org/10.1016/S0166-0934(03)00081-8

48. Pratelli A, Martella V, Elia G, et al (2001) Severe enteric disease in an animal shelter associated with dual infections by canine adenovirus type 1 and canine coronavirus. J Vet Med Ser B 48:385-392. https://doi.org/10.1046/j.1439-0450.2001.00466.x

49. Quintero-Gil C, Rendon-Marin S, Martinez-Gutierrez M, Ruiz-Saenz J (2019) Origin of canine distemper virus: Consolidating evidence to understand potential zoonoses. Front Microbiol 10:. https://doi.org/10.3389/fmicb.2019.01982

50. Ramidi A, Ganji VK, Buddala B, et al (2020) E3 gene-based genetic characterization of canine adenovirus-2 isolated from cases of canine gastroenteritis in india revealed a novel group of the virus. Intervirology 62:216-221.

https://doi.org/10.1159/000507329

51. Romanutti C, Keller L, La Torre J, et al (2020) Virus isolation and full-length genome sequencing of a representative canine distemper virus wild type strain of the South America 2 clade. J Virol Methods 279:.

https://doi.org/10.1016/j.jviromet.2020.113857

52. Sambrook J, Russell DW (2001) Molecular cloning: a laboratory manual. Cold Spring Harbor Laboratory Press

53. Sharma S, Dhar P, Thakur A, et al (2016) First detection of canine parvovirus type 2b from diarrheic dogs in Himachal Pradesh. Vet World 9:964-969. https://doi.org/10.14202/vetworld.2016.964-969

54. Swati, Deka D, Uppal SK, Verma R (2015) Isolation and phylogenetic characterization of Canine distemper virus from India. VirusDisease 26:133-140. https://doi.org/10.1007/s13337-015-0256-x

55. Takano T, Takashina M, Doki T, Hohdatsu T (2015) Detection of canine astrovirus in dogs with diarrhea in Japan. Arch Virol 160:1549-1553. https://doi.org/10.1007/s00705-015-2405-3

56. Toffan A, Jonassen CM, De Battisti C, et al (2009) Genetic characterization of a new astrovirus detected in dogs suffering from diarrhoea. Vet Microbiol 139:147-152. https://doi.org/10.1016/j.vetmic.2009.04.031

57. Von Messling V, Zimmer G, Herrler G, et al (2001) The hemagglutinin of canine distemper virus determines tropism and cytopathogenicity. J Virol 75:6418-27. https://doi.org/10.1128/JVI.75.14.6418-6427.2001

58. Wang X, Li C, Guo D, et al (2016) Co-Circulation of Canine Coronavirus I and Ila/b with High Prevalence and Genetic Diversity in Heilongjiang Province, Northeast China. PLoS One 11:e0146975. https://doi.org/10.1371/journal.pone.0146975

59. Zhao JJ, Yan XJ, Chai XL, et al (2010) Phylogenetic analysis of the haemagglutinin gene of canine distemper virus strains detected from breeding foxes, raccoon dogs and minks in China. Vet Microbiol 140:34-42.

https://doi.org/10.1016/j.vetmic.2009.07.010

60. Zhong Z, Liang L, Zhao J, et al (2014) First isolation of new canine parvovirus 2a from Tibetan Mastiff and global analysis of the full-length VP2 gene of canine parvoviruses 2 in China. Int J Mol Sci 15:12166-12187.

https://doi.org/10.3390/ijms150712166

61. Zhou H, Liu L, Li R, et al (2017a) Detection and genetic characterization of canine astroviruses in pet dogs in Guangxi, China. Virol J 14:156. https://doi.org/10.1186/s12985-017-0823-4

62. Zhou P, Zeng W, Zhang X, Li S (2017b) The genetic evolution of canine parvovirus - A new perspective. PLoS One 12:. https://doi.org/10.1371/journal.pone.0175035

63. Zobba R, Visco S, Sotgiu F, et al (2021) Molecular survey of parvovirus, astrovirus, coronavirus, and calicivirus in symptomatic dogs. Vet Res Commun 45:31-40. https://doi.org/10.1007/s11259-020-09785-w

\section{Figures}


a

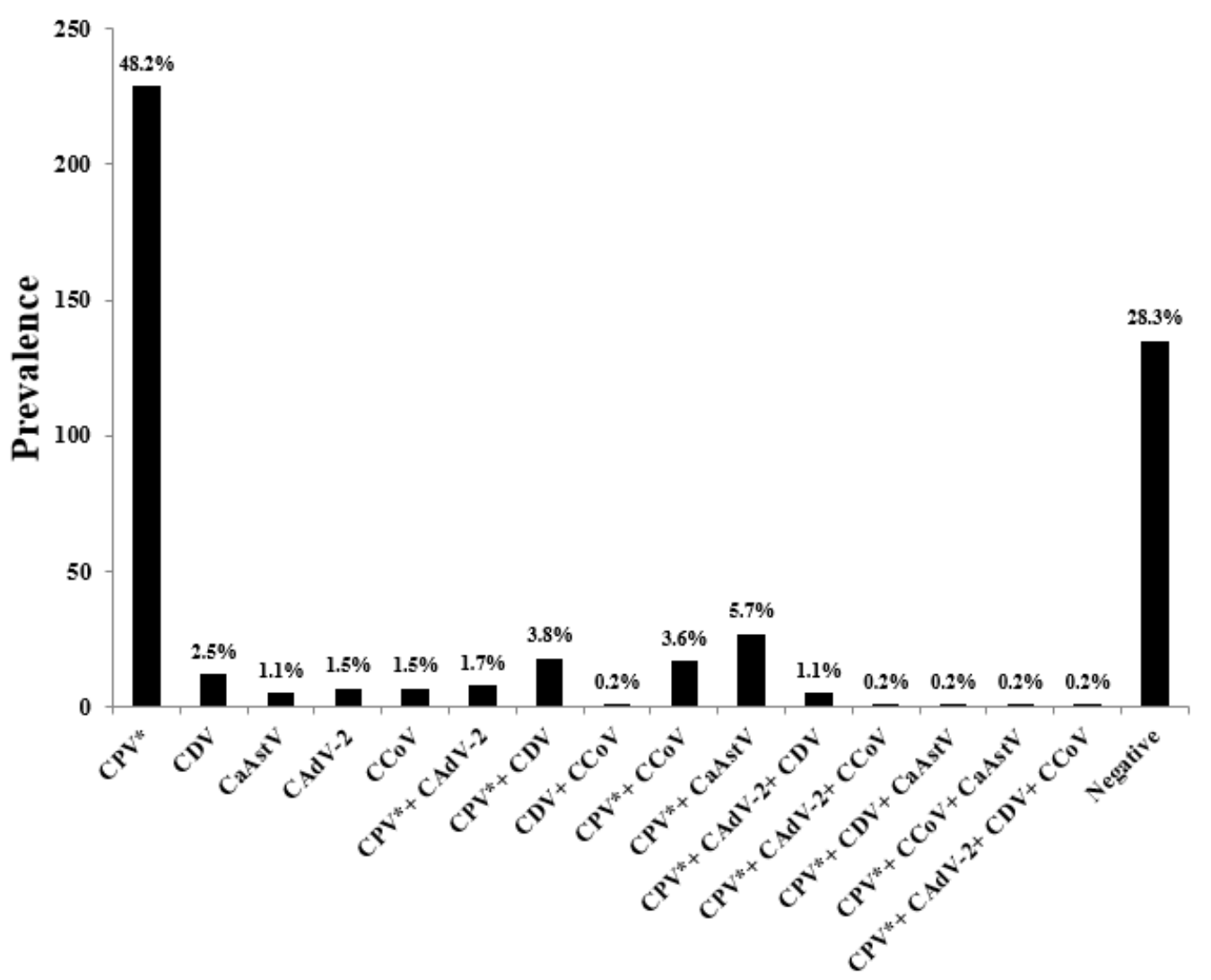

b

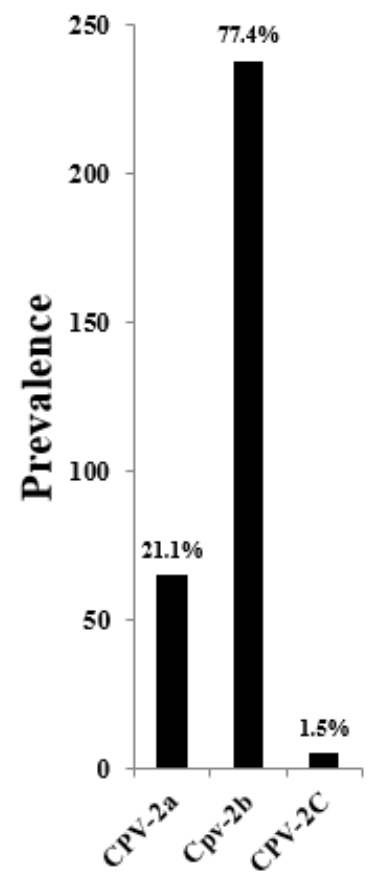

\section{Figure 1}

Prevalence of canine enteric viruses. a) The prevalence of different canine enteric viruses during the year 2018-21 in the Hyderabad region of Telangana state in India was depicted with bar diagram. The length of the bar indicates number of samples tested positive (Y-axis) for each virus either individually or in mixed infection (X-axis). The percentage above the bar indicates the prevalence rate for that particular virus. CPV* indicates either CPV-2/2a/2b/2c. b) The antigenic prevalence of CPV-2/2a/2b/2c during the year 2018-21 in Hyderabad region of Telangana state in India was depicted with bar diagram. The length of the bar indicates number of samples tested positive ( $\mathrm{Y}$-axis) for respective antigenic variant (X-axis). The percentage above the bar indicates the prevalence rate for that particular antigenic variant.

A)

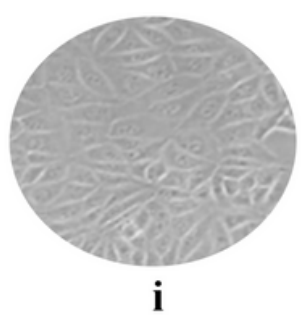

B)

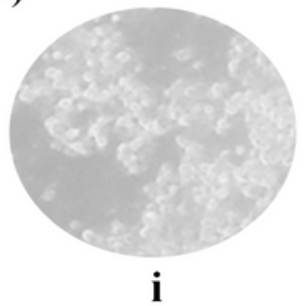

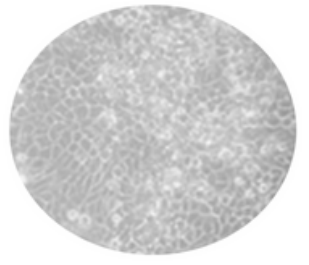

ii

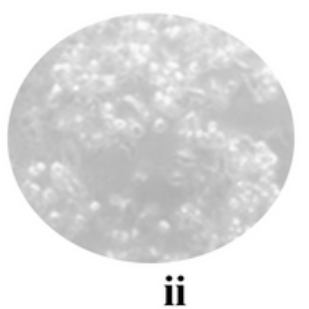

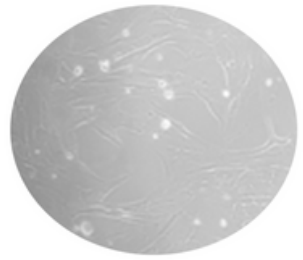

iii

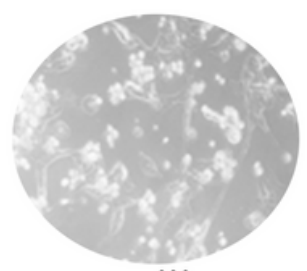

iii

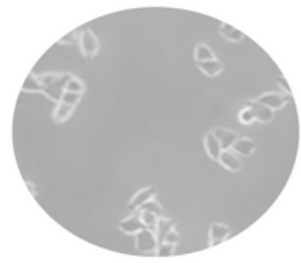

iv

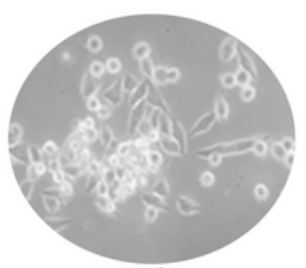

iv

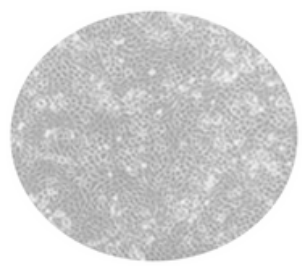

$\mathbf{v}$

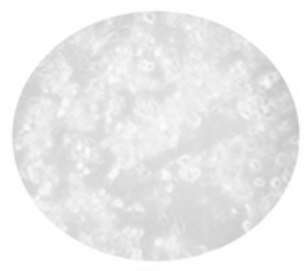

$\mathbf{V}$ 
Figure 2

Isolation of canine enteric viruses. Panel A shows healthy cell culture images taken at 20X (total of 200X) magnification whereas panel $B$ shows virus infected cell culture images taken at 20X (total of 200X) magnification. From left to right (i) MDCK/CPV (ii) MDCK/CAdV-2 (iii) A-72/CCoV (iv) B95a/CDV (v) MDCK/CaAstV.

a)

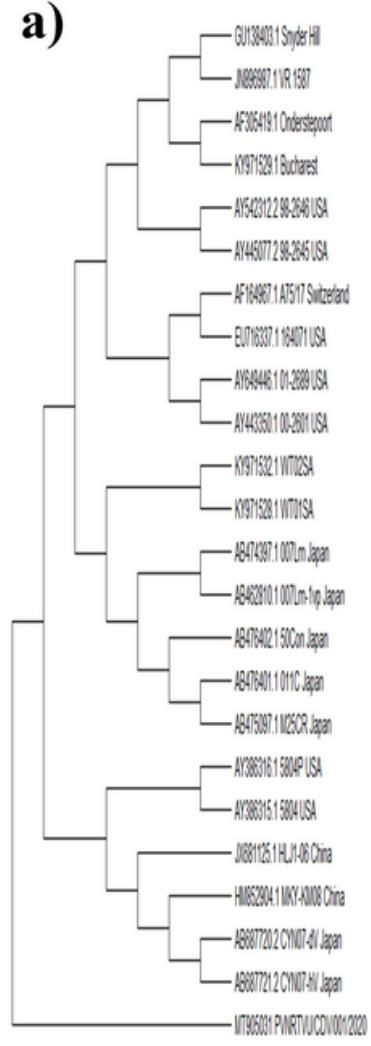

b)

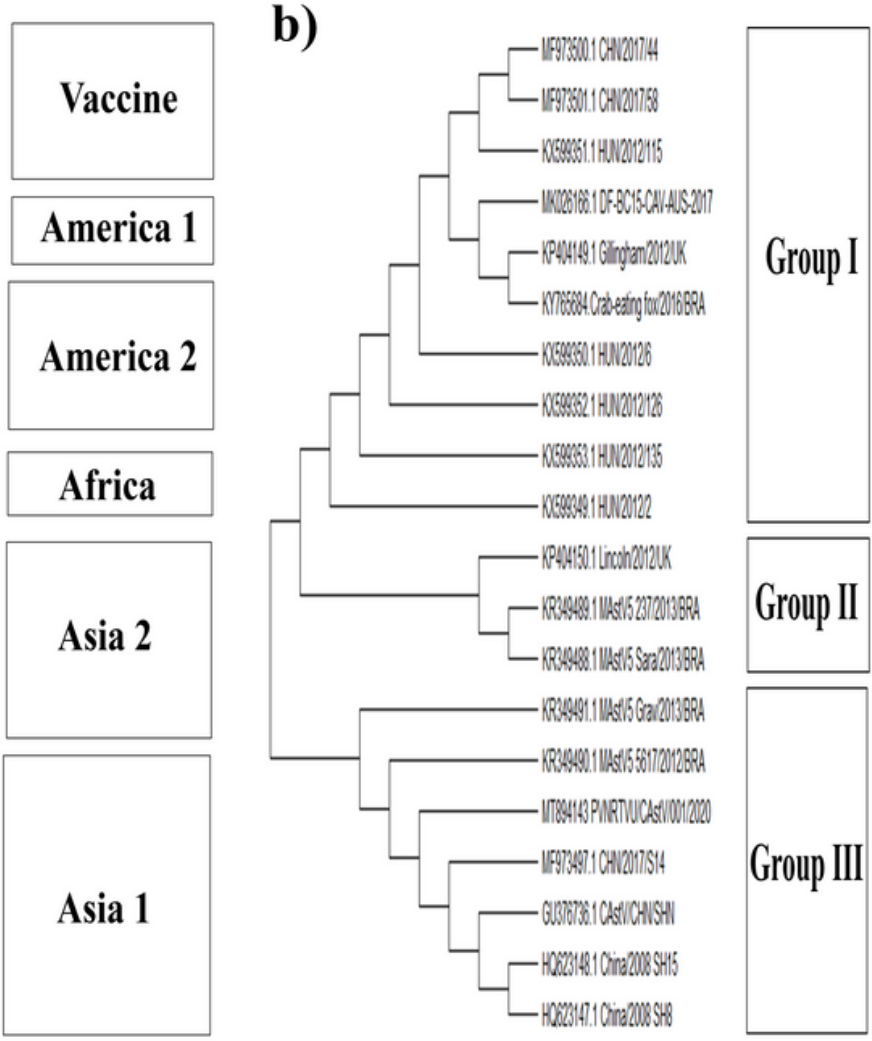

c)

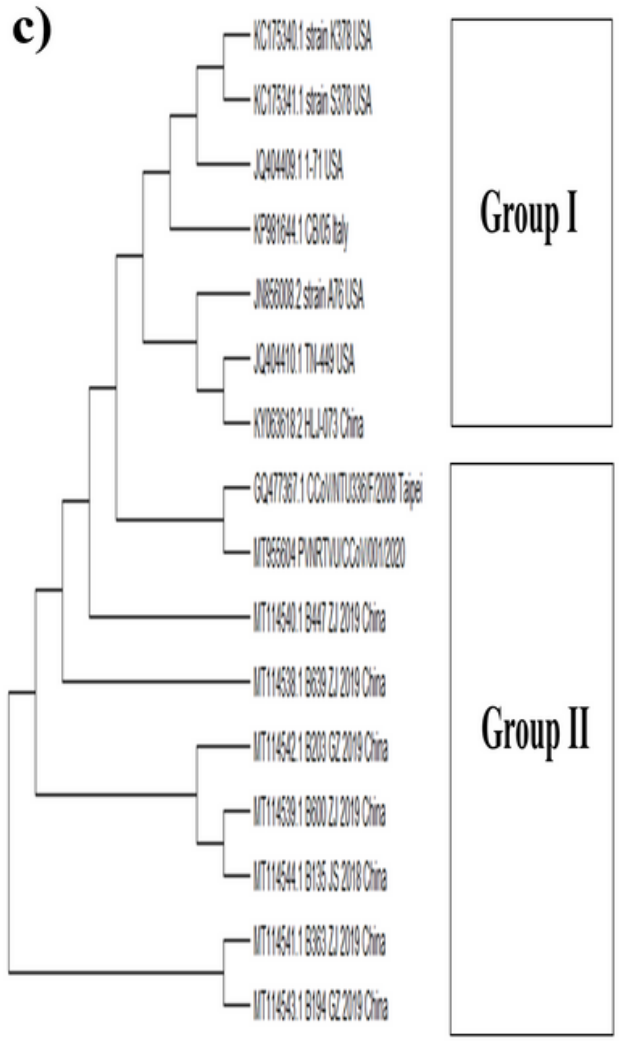

Figure 3

Phylogenetic analysis of the whole genome of current isolates against published sequences from NCBI database. The CDV isolates from current study clustered with Asia 1 lineage (a), CaAstV isolates from current study clustered with group III that consists of China and Brazil (b), CCoV isolates from current study clustered with group II that consists of China and Taipei isolates. 


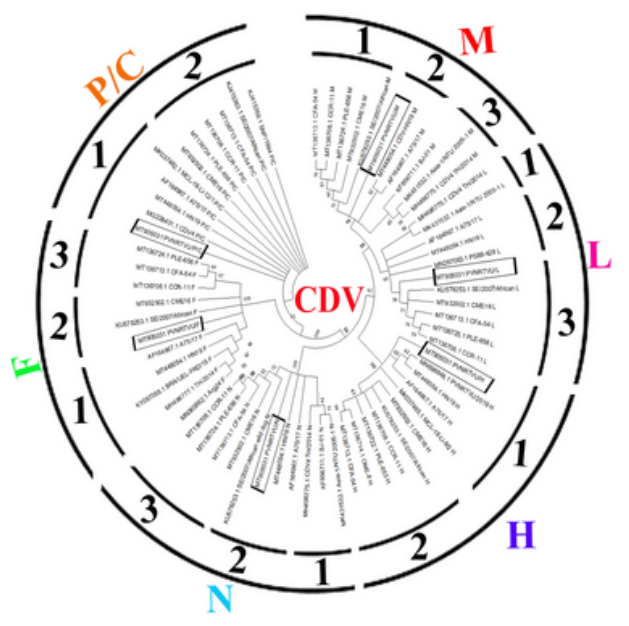

(a)

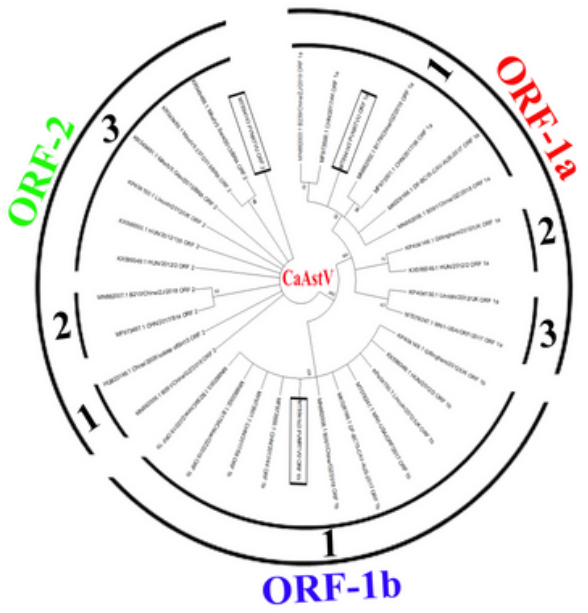

(b)

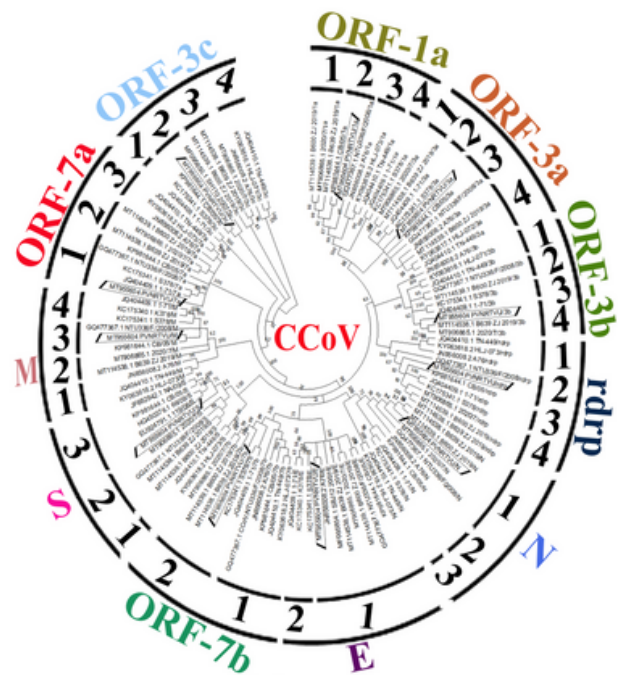

(c)

Figure 4

Phylogenetic analysis based on the individual ORF of current isolates against published sequences from NCBI database. The phylogenetic tree was reconstructed for CDV (a), CaAstV (b) and CCoV (c) for individual genes with ten isolates per gene in a single analysis for each virus. The clusters were divided into groups based on relatedness.

\section{Supplementary Files}

This is a list of supplementary files associated with this preprint. Click to download.

- Supplementarydata.docx 